\title{
Influence of Prolonged use of Desensitizing Dentifrices on Dentin Bond Strength of Self-Etching Adhesive System
}

\author{
Influencia del Uso Prolongado de Pasta Dentífrica Desensibilizante en la \\ Fuerza de Unión de la Dentina de un Sistema Adhesivo Autocondicionante
}

\author{
Juliana Dias Aguiar;; Aline Cristina Silva de Amorim"; Igor Studart Medeiros ${ }^{*+*}$ \\ Mário Honorato Silva e Souza Júnior ${ }^{*+* *}$ \& Sandro Cordeiro Loretto ${ }^{*+*+*}$
}

AGUIAR, J. D.; DE AMORIM, A. C. S.; MEDEIROS, I. S.; SOUZA JÚNIOR, M. H. S. \& LORETTO, S. C. Influence of prolonged use of desensitizing dentifrices on dentin bond strength of self-etching adhesive system. Int. J. Odontostomat., 10(1):135-142, 2016.

ABSTRACT: Dentin hypersensitivity is a relatively common clinical condition, which affects a large part of the world's population. The objective of this study was to evaluate the influence of previous and prolonged treatment with desensitizing dentifrices (DD) on bond strength to dentin, promoted by a self-etching adhesive system. Seventy non-carious bovine incisors were used, and divided into five groups $(n=14)$, according to the desensitizing toothpaste used, such as, G1: distilled water (WATER) (control); G2: Colgate Total 12 (CT12) (control); G3: Colgate Sensitive Pro-Relief (CSPR); G4: Sensodyne Rapid Relief (SRR); G5: Sensodyne Repair \& Protect (SRP). Teeth had their buccal surfaces flattened until the exposure of dentin, and fragments of $4 \times 4 \times 2 \mathrm{~mm}$ were obtained. Fragments were included in polyvinyl chloride (PVC) cylinders and exposed to $17 \%$ EDTA for $1 \mathrm{~min}$. Subsequently, specimens were submitted to 20000 cycles of simulated dental toothbrushing. After $24 \mathrm{~h}$ in artificial saliva, specimens were hybridized (Clearfil SE Bond - Kuraray), as well as resin composite cylinders built on dentin surfaces. Samples were stored in distilled water, at $37^{\circ} \mathrm{C}$ for $24 \mathrm{~h}$, and the shear bond strength was determined. The highest bond strength (MPa) value was seen in CT12 group (4.39), and the lowest one in CSPR group (3.34). Data were statistically analyzed by 1 -way ANOVA $(\partial=0.05)$, and results showed that there were no significant differences $(p=0.5986)$ considering the DD factor. The predominant fracture pattern was cohesive on dentin. The previous and prolonged use of different DD did not affect dentin bond strength promoted by a self-etching adhesive system.

KEY WORDS: dentin desensitizing agents, dentifrices, dentin-bonding agents, dentin sensitivity.

\section{INTRODUCTION}

Dentin hypersensitivity $(\mathrm{DH})$ is a relatively common clinical condition, characterized by a shortterm acute pain, due to the exposure of the dentin in response to a variety of stimulation, such as thermal, evaporative, tactile, osmotic or chemical, which can't be attributed to any other form of defect or dental pathology. Studies report a prevalence of 3 to $57 \%$ of the population, affecting more often individuals between 20-40 years of age (Sharif et al., 2013; Parolia et al., 2011; Porto et al., 2009; West, 2000).

Theories have been proposed over the years in order to explain the mechanism of pain transmission, through the dentin. The current hypothesis accepted is the hydrodynamic theory (Brännström et al., 1967), in which the fluids within the dentin tubules are disrupted by physical, thermal or osmotic stimuli, allowing this disorder or movement to stimulate neural receptors and consequently, causing pain sensation. The foundation of this theory is that the dentin tubules, filled with fluids, are open to the oral cavity, as well as inside the pulp (Sharif et al., 2013; Parolia et al., 2011; Porto et al., 2009; West, 2000).

Thus, several alternatives have been tested and used in $\mathrm{DH}$ control, through either an occlusive action,

\footnotetext{
Postgraduate Program in Dentistry, School of Dentistry, Federal University of Pará, Belém, Brazil.

* Department of Restorative Dentistry, School of Dentistry, Federal University of Pará, Belém, Brazil.

"** Postdoc; Postgraduate Program in Dentistry, School of Dentistry, University of São Paulo, São Paulo, Brazil.

**** Postdoc; Postgraduate Program in Dentistry, School of Dentistry, Federal University of Pará, Belém, Brazil.

${ }^{* * * * * *}$ Postgraduate Program in Dentistry, School of Dentistry, Federal University of Pará, Belém, Brazil.
} 
obliterating the dentin tubules; or a neural action, depolarizing the membranes of the nerve fibers, blocking the axonal action and the passage of the nervous stimuli. Among the most used substances, selfapplied home-applied desensitizing agents stand out, due to how easily they can be obtained, and excuse the necessity of laboratories and professional prescription (Porto et al.).

Two promising desensitizing agents were recently introduced in the form of dentifrices, which are $8 \%$ strontium acetate and $8 \%$ arginine/calcium carbonate-based. The first substance acts occluding the open dentin tubules through the formation of strontium and silica plugs, as the second connects, through ionic bonds, to the dentin. Both substances act, according to manufacturers, instantly and permanently, through their daily use, which has been demonstrated clinically by significant reduction in dentin hypersensitivity, formatting a robust occlusive layer with the ability to resist acids present in a common nutritional diets (West et al., 2013).

Even more, a new technology known commercially as Novamin ${ }^{\circledR}$ was launched as an alternative in the treatment of $\mathrm{DH}$. It corresponds to 5 $\%$ calcium sodium phosphosilicate, an amorphous compound containing calcium, sodium, phosphate and silica. This technology was first introduced in the late $60 \mathrm{~s}$, and is recommended as a bone regeneration material. Subsequently, in the late 90 s, it was modified in order to be used as a dentin remineralization agent (Wang et al., 2010).

In some cases of $\mathrm{DH}$, the use of a more invasive approach, with restorative materials, is also acknowledged when conservative therapies have not been successful, or in the presence of a considerable amount of tooth loss, as in some cervical non-carious lesions (West et al.).

Numerous efforts have been undertaken in order to improve and even facilitate adhesive mechanisms to dental structures. In this regard, self-etching systems come with a proposal to simplify clinical procedures, reducing its sensitivity, and favoring the bonding process (Van Meerbeek et al., 2011).

Considering that restorative treatments are constantly object of scientific studies, and DH is a reality found in society, the possibility that both conditions could involve patients simultaneously, justifies the need to evaluate whether the use of occlusive therapy, through desensitizing agents, could interfere with the bonding to dentin produced by self-etching adhesive systems.

Therefore, the aim of this study was to evaluate the influence of prolonged (simulated) use of desensitizing toothpastes with $8 \%$ arginine/calcium carbonate, $8 \%$ strontium acetate and $5 \%$ calcium sodium phosphosilicate, on bond strength of a two steps self-etching adhesive system to dentin. The hypothesis to be tested is that prior and prolonged use of desensitizing toothpastes will interfere with bond strength of the adhesive system to dentin.

\section{MATERIAL AND METHOD}

The project was approved by the Ethics Committee for Experimental Research with Animals (CEPAE) of the Federal University of Pará (UFPA) (protocol 169/13).

Seventy (70) bovine incisors were obtained, washed in running water and stored in a $0.1 \%$ thymol disinfectant solution for a period of 1 (one) week. Subsequently, all teeth were stored in distilled water $\left(4^{\circ} \mathrm{C}\right)$, renewed every week, until the moment of the experiment, and not exceeding a maximum period of 6 (six) months of storage. Then, teeth were subjected to a prophylaxis using water and pumice. They were analyzed under a stereomicroscope at $\times 10$ magnification, to detect any possible presence of cracks and/or fractures, which would eliminate the specimen as a viable sample.

The materials used in this study are listed in Table I (trade name, classification, composition and batch number). The division of the experimental groups $(n=14)$ is shown in Table II.

Initially, the buccal surface of each tooth was ground with an abrasive silicon carbide paper 180-grit (3M, Sumaré, SP, Brazil) until the exposure of dentin. The specimens were marked with the aid of a digital caliper (Mitutoyo, São Paulo, SP, Brazil), in order to delimitate the area that would be cut (middle third of the crown). Teeth were sectioned with a double-sided diamond disc (KG Sorensen, Cotia, SP, Brazil) to obtain dentin blocks of $4 \times 4 \times 2 \mathrm{~mm}$ dimension. These blocks were then embedded in acrylic resin (JET, Classic, Campo Limpo Paulista, SP, Brazil) using polyvinyl chloride (PVC) cylinders. 
Table I. Description of the materials used in the experiment, containing their trade names (manufacturers), classification, composition and batch.

\begin{tabular}{|c|c|c|c|}
\hline Material (manufacturer) & Classification & Composition & $\begin{array}{l}\text { Batch } \\
\text { number }\end{array}$ \\
\hline $\begin{array}{l}\text { Colgate Total - Clean Mint } \\
- \\
\text { (Colgate-Palmolive) }\end{array}$ & Toothpaste & $\begin{array}{l}\text { Sodium Fluoride } 0.24 \%(0.14 \% \text { w/v fluoride ion }) \text {, water, hydrated } \\
\text { silica, glycerin, sorbitol, PVM/MA copolymer, sodium lauryl sulfate, } \\
\text { cellulose gum, flavor, sodium hydroxide, carrageenan, propylene } \\
\text { glycol, so dium saccharin, titanium dioxide. }\end{array}$ & 3060BR122F \\
\hline $\begin{array}{l}\text { Colgate Sensitive } \\
\text { Pró-Alívio (Colgate- } \\
\text { Palmolive) }\end{array}$ & $\begin{array}{l}\text { Desensitizing } \\
\text { toothpaste }\end{array}$ & $\begin{array}{l}\text { Arginine } 8 \% \text {, } 1450 \mathrm{ppm} \text { fluoride, calcium carbonate, sorbitol, water, } \\
\text { bicarbonate, sodium lauryl sulfate, sodium monofluorophosphate } \\
1.10 \% \text {, aroma, sodium silicate, cellulose gum, sodium bicarbonate, } \\
\text { titanium dioxide, potassium acesulfame, xanthan gum, sucralose. }\end{array}$ & 2323BR122C \\
\hline $\begin{array}{l}\text { Sensodyne Rapid } \\
\text { Releif (GlaxoSmithKline) }\end{array}$ & $\begin{array}{l}\text { Desensitizing } \\
\text { toothpaste }\end{array}$ & $\begin{array}{l}\text { Strontium acetate, water, sorbitol, hydrated silica, glycerin, contains } \\
\text { sodium fluoride } 0.23 \% \mathrm{w} / \mathrm{w}(1040 \mathrm{ppm} \text { fluoride), sodium methyl } \\
\text { cocoyl taurate, xanthan gum, titanium dioxide, aroma, sodium } \\
\text { saccharin, sodium fluoride, sodium propylparaben, sodium } \\
\text { methylparaben, limonene. }\end{array}$ & 062BG2 \\
\hline $\begin{array}{l}\text { Sensodyne Repair \& } \\
\text { Protect (GlaxoSmithKline) }\end{array}$ & $\begin{array}{l}\text { Desensitizing } \\
\text { toothpaste }\end{array}$ & $\begin{array}{l}\text { Glycerin, PEG-8, silica, calcium sodium phosphosilicate (Novamin), } \\
\text { sodium lauryl sulfate, sodium monofluorophosphate, aroma, } \\
\text { titanium dioxide, carbomer, potassium acesulfame, limonene, } \\
\text { contains sodium monofluorophosphate } 1.08 \% \mathrm{w} / \mathrm{w}(1450 \mathrm{ppm} \\
\text { fluoride). }\end{array}$ & $322 \mathrm{CG} 1$ \\
\hline $\begin{array}{l}\text { Clearfil SE Bo } \quad \text { nd } \\
\text { (Kuraray) }\end{array}$ & $\begin{array}{l}\text { Self-etching } \\
\text { bonding system }\end{array}$ & $\begin{array}{l}\text { Primer: 10-Methacryloyloxydecyl dihydrogen phosphate, 2- } \\
\text { hydroxyethyl methacrylate, hydrophilic aliphatic dimethacrylate, dl- } \\
\text { camphorquinone, water accelerators, dyes and others. } \\
\text { BOND: bisphenol A diglycidylmethacrylate, 2-hydroxyethyl } \\
\text { methacrylate, 10-methacryloyloxydecyl dihydrogen phosphate, } \\
\text { hydrophobic aliphatic methacrylate, colloidal sílica, dl- } \\
\text { camphorquinone, initiators, accelerators and others. }\end{array}$ & $01147 A$ \\
\hline $\begin{array}{l}\text { Filtek Z350 XT (A2B) } \\
\text { (3M/ESPE) }\end{array}$ & Resin composite & $\begin{array}{l}\text { Bisphenol A diglycidyl dimethacrylate ether (BIS- GMA), bisphenol } \\
\text { A polyethylene glycol diether dimethacrylate (BIS-EMA), silanated } \\
\text { silica, zirconia and ceramic, diurethane dimethacrylate, } \\
\text { polyethylene glycol dimethacrylate, triethylene glycol (TEG-DMA), } \\
2,6-\text { di-tert-butyl-p-cresol (BHT) and pigments. } \\
\text { EDTA } 17 \%\end{array}$ & N205916BR \\
\hline $\begin{array}{l}\text { Artificial Saliva (Fórmula } \\
\text { Farmácia de } \\
\text { Manipulação) }\end{array}$ & --- & $\begin{array}{l}2190 \mathrm{mg} \text { so dium bicarbonate, } 1270 \mathrm{mg} \text { potassium phosphate, } 125 \\
\text { mg magnesium chloride, } 820 \mathrm{mg} \text { potassium chloride, } 100 \mathrm{mg} \\
\text { nipagin, } 441 \mathrm{mg} \text { calcium chloride, } 4,5 \mathrm{mg} \text { sodium fluoride, } 24 \mathrm{mg} \\
\text { sorbitol, } 8 \mathrm{mg} \text { carboxymethylcellulose, and } 3000 \mathrm{ml} \text { distilled water } \\
(\mathrm{pH}=7) \text {. }\end{array}$ & --- \\
\hline
\end{tabular}

Table II. Division of the experimental groups according to the type of toothpaste and desensitizing agent (active ingredient).

\begin{tabular}{llc}
\hline Group & Tooth paste & Desensitizing agent (active ingredient) \\
\hline WATER & Distilled water (negative control I) & -- \\
CT12 & Colgate Total 12 (negative control II) & -- \\
CSPR & Colgate Sensitive Pro-Relief & $8 \%$ arginine/calcium carbonate (Pro-Argin ${ }^{\mathrm{TM}}$ ) \\
SRR & Sensodyne Rapid Relief & $8 \%$ strontium acetate \\
SRP & Sensodyne Repair \& Protect & $5 \%$ calcium sodium phosphosilicate (Novamin $\left.{ }^{\circledR}\right)$
\end{tabular}

The specimens' dentin surface were ground, under refrigeration, using 400-grit and 600-grit silicon carbide sandpaper (3M, Sumaré, SP, Brazil), in a horizontal polishing machine (Aropol-E - Arotec, Cotia, SP, Brazil). Soon after, the samples received an application of a 17 \% EDTA solution (Formula \& Action, São Paulo, SP, Brazil), for 1 (one) minute, to clean the surface and simulate a hypersensitive dentin.
For tooth brushing simulation, specific toothpastes were used as described in Table II. Distilled water and Colgate Total 12 toothpaste were used as negative controls, since they do not have active ingredients for dentin desensitization.

A brushing simulation machine (Department of biomaterials and oral biology, FOUSP, São Paulo, SP, 
Brazil) was used in order to simulate the tooth bushing process. Soft toothbrushes (Oral-B Indicator Plus 40, Manaus, AM, Brazil) were placed in the machine and attached to its projections (brushing arms). Specimens were accommodated in round plastic containers (brushing containers), and positioned parallel to the container's base, with a $1 \mathrm{~mm}$ suspension, to allow an efficient, perpendicular and uniform action of the toothbrush bristles.

Twenty thousand brushing cycles were performed (approximately two year period of tooth brushing) with the speed of 58 cycles per minute and a load application of $200 \mathrm{~g}(2 \mathrm{~N})$. A complete cycle was considered as a total back-and-forth movement of the toothbrush. During the test, a solution of distilled water/ toothpaste (mass ratio of 2:1), or $90 \mathrm{~g}$ of toothpaste for $180 \mathrm{~g}$ of distilled water was used. This preparation was performed just before its use, with the purpose of preserving the solution's characteristics.

After 10000 cycles, the toothbrushes were replaced with new ones and the brushing containers were changed positions. The brushing containers were rotated $180^{\circ}$ so that the specimens' position could change and the toothbrushes would brush specimens in a different direction. After this process, the specimens were carefully removed and immediately washed in running water to remove any abrasive particles that could have been on the specimens' surfaces, from the solution. Then, the brushed specimens were stored for a period of $24 \mathrm{~h}$, in artificial saliva $\left(37^{\circ} \mathrm{C}\right)$. Subsequently, the adhesive bonding was performed.

In order to standardize the bonding area of all groups, a central holed adhesive tape, with a $3.0 \mathrm{~mm}$ diameter, was positioned on the dentin surface. The self-etching adhesive system Clearfil SE Bond (Kuraray Co. Ltd., Osaka, Japan) was applied as followed: selfetching primer for $20 \mathrm{~s}$, gentle mild air jet, application of the bonding agent, another mild air jet, and photoactivation for $10 \mathrm{~s}$.
A metallic split device, that formed a central hole of $5 \mathrm{~mm}$ in height and $3 \mathrm{~mm}$ in diameter, was used to build the resin composite cylinders on the hybridized dentin surfaces, which matched with the tape marked area. The composite resin Filtek Z350 XT (3M Espe, Sumaré, SP, Brazil) was inserted using two increments, each increment was cured for $20 \mathrm{~s}$, light-cured with Ultrablue D-2000 led (DMC, São Carlos, SP, Brazil) with an intensity of $900 \pm 10 \mathrm{~mW} / \mathrm{cm}^{2}$, measured by a radiometer.

After manufacturing the composite resin cylinders, the specimens were stored in distilled water $\left(37^{\circ} \mathrm{C} / 24 \mathrm{~h}\right)$, and then submitted to shear bond strength test. This test was accomplished at a crosshead speed of $0.5 \mathrm{~mm} / \mathrm{min}$, with a universal testing machine (KE Kratos, Kratos Industrial Equipment, Cotia, SP, Brazil). Data were submitted to one-way ANOVA test $(\alpha=0.05)$.

Once the mechanical test stage was concluded, the specimens were taken to the stereomicroscope at 10x magnification for fracture pattern observation, which were classified as adhesive, cohesive in dentin, cohesive in composite resin and mixed.

\section{RESULTS}

The mean (standard deviation) of shear strength (MPa) for each experimental group was, respectively: G1 (WATER) - 3.68 (1.55); G2 (CT12) - 4.39 (2.42); G3 (CSPR) - 3.34 (2.15); G4 (SRR) - 4.23 (1.62); G5 (SRP) - 4.20 (2.06). Through 1-way ANOVA test, no significant differences, regarding the toothpaste factor, was found, therefore, no statistical differences were established between the study groups $(p=0.5986)$ (Table III).

The predominant type of fracture was cohesive in dentin $(45.71 \%)$.

Table III. Mean (standard deviation) of shear strength (MPa) of the experimental groups $(\alpha=0,05)$.

\begin{tabular}{llcc}
\hline Group & Tooth paste & $\begin{array}{c}\text { Mean } \\
(\mathbf{S D})\end{array}$ & $\begin{array}{c}\text { Comparisons } \\
\text { between groups }\end{array}$ \\
\hline G1 & Distilled water & $3.68( \pm 1.55)$ & $\mathrm{A}$ \\
G2 & Colgate Total 12 & $4.39( \pm 2.42)$ & $\mathrm{A}$ \\
G3 & Colgate Sensitive Pro-Relief & $3.34( \pm 2.15)$ & $\mathrm{A}$ \\
G4 & Sensodyne Rapid Relief & $4.23( \pm 1.62)$ & $\mathrm{A}$ \\
G5 & Sensodyne Repair \& Protect & $4.20( \pm 2.06)$ & $\mathrm{A}$ \\
\hline
\end{tabular}

Statistically similar means are indicat

Influence of Prolonged use of Desensitizing 


\section{DISCUSSION}

Results showed, after prolonged use of desensitizing toothpastes that contain $8 \%$ arginine/ calcium carbonate (CSPR), $8 \%$ strontium acetate (SRR) and $5 \%$ calcium sodium phosphosilicate (SRP), that the dentin bond strength values were statistically similar to the control groups (WATER and CT12). Thus, the tested hypothesis must be rejected, as the desensitizing toothpastes tested did not significantly interfere with dentin bond strength.

There are several products used for $\mathrm{DH}$ management, from professional to domestic use. Although, many products have been developed to seal dentin tubules, the effects are usually temporary and $\mathrm{DH}$ repeats itself, when the obstructing substances are removed, due to erosive activities from the daily diet (West et al.).

Nonetheless, in some situations, $\mathrm{DH}$ requires a more invasive treatment with the use of restorative material, when conservative therapies have been unsuccessful, or in cases of larger loss of dental structure, such as non-carious cervical lesions. In these situations, the prior application of desensitizing agents influences negatively the bonding agents to dentin, since the bonding systems could not adequately infiltrate the dentin structure and, therefore, lead to lower bond strength and gap formation in the bonding interface (Awang et al., 2007; Aranha et al., 2006; Pei et al., 2013).

Although many clinical and laboratory studies about $\mathrm{DH}$ have described the different mechanisms of substances present in these remineralizing and desensitizing toothpastes, and its efficacy to ease the sensations of pain (West et al.; Wang et al.; Earl et al., 2011; Lavenser et al., 2010; Du Min et al., 2008), little is known about the influence of prolonged use of these dentifrices on dentin tissue. In the present investigation, $8 \%$ arginine/calcium carbonate (Pro-ArginTM) and 5 $\%$ calcium sodium phosphosilicate $\left(\operatorname{NovaMin}^{\circledR}\right)$, regardless of their different mechanisms and active desensitization components, did not interfere with the bond strength, when compared to the negative controls (distilled water and Colgate Total 12).

Considering Colgate Sensitive Pro-Relief desensitizing toothpaste, our results are consistent with other studies in the literature (Pei et al.; Marchan et al., 2014; Yang et al., 2014; Canares et al.,
2012), which presented that the use of this toothpaste did not affect bond strength, when compared to the control group, observing even a slight increase in the values of bond strength (Canares et al.).

It is well known that the use of desensitizing toothpastes with $8 \%$ arginine/calcium carbonate (ProArginTM) and $5 \%$ calcium sodium phosphosilicate $\left(\right.$ NovaMin $\left.^{\circledR}\right)$ is capable of inducing in situ mineral formation, creating a rich calcium layer on the dentin surface (West et al.; Wang et al.; Lavander et al.; Du Min et al.). In this matter, specific functional monomers, such as 10-MDP, present in Clearfil SE Bond bonding system, which was used in this study, proven to have chemical bonding capacity to calcium present in hydroxyapatite (Van Meerbeek et al.; Yoshida et al., 2004). Therefore, the similarities in bond strength results from groups submitted to these desensitizing toothpastes and control groups can be credited, even if partly, to a possible chemical interaction between specific components present in the self-etching bonding system and the mineralized layer formed on dentin surface by desensitizing toothpastes (Colgate Sensitive Pro-Relief and Sensodyne Repair \& Protect), since, theoretically, the substances formed on dentin surface and within its tubules could act as a physical barrier preventing a suitable infiltration of bonding agents, and consequently suspending the hybridization process.

Nevertheless, it is also acknowledged that the mineral deposits formed by the desensitizing toothpastes mentioned above are unstable (Yang et al.), or not tenacious enough, to affect the formation of the hybrid layer (Marchan et al., 2014), therefore, not interfering on bond strength. Studies that used conventional bonding systems in dentin hybridization, which previously were exposed to desensitizing dentifrices, attributed their results to phosphoric acid. The acid probably dissolves the calcium phosphate deposits in the dentin tubules until it encounters the mineralized dentin matrix, leading to a reopening of these tubules, and allowing the infiltration of resin monomers, favoring the bonding (Yang et al.).

Although the two-step, self-etch, bonding system (Clearfil SE Bond) used in present study is notably less acidic when compared to phosphoric acid (Van Meerbeek et al.), it is possible that the same justification used previously could be responsible for the results obtained. That is, the mineral deposits formed on the dentin's surface were not able to act as a physical barrier that could compromise dentin hybridization. 
However, our results differ from Cavalcanti et al. (2013), which observed a significant reduction in bond strength to dentin after the use of a desensitizing dentifrice Colgate Sensitive Pro-Relief, when associated to a one-step, self-etching, bonding system. Although those bonding agents showed higher acidity compared to the one used in the present study (twostep, self-etching) (Van Meerbeek et al.), which could make dentin hybridization less sensitive to the previous application of desensitizing agents, other aspects must be considered when referring to one-step, self-etching, systems: the inhibition of polymerization by the acidity of this type of adhesive system, the adhesive layer thickness, phase separation between hydrophilic and hydrophobic components, and greater sensitivity to hydrolysis (Van Meerbeek et al.).

Regarding the desensitizing Sensodyne Rapid Relief ( $8 \%$ strontium acetate) toothpaste, its previous application did not significantly interfere with the adhesive bond to dentin, even though literature shows that the active substance, present in this toothpaste, promotes a deeper obliteration of dentin tubules, which proves to be more resistant to acid challenges than those present in desensitizing toothpaste with arginine (Parkinson \& Willson, 2011). Yet again, it is assumable that the deposits of strontium salts, formed on dentin surface, are unstable enough to not compromise the hybridization process.

Finally, a methodological matter deserves to be noted, concerning the mechanical test that was chosen. Although shear represents one of the most commonly used test in the evaluation of the strength of bonding interfaces (al-Salehi \& Burke, 1997), criticism is directed to the trial's design, due to the fact of how it allows the shear load to easily be transformed into bending forces and cleavage. This situation generates an uneven tension distribution across the bonding interface, and consequently compromises the obtained results for the accurate evaluation of the strength on the bonding area (DeHoff et al., 1995; Sinhoreti et al., 2001).

These critical remarks are often found when the shear bond strength test is performed with a chisel. Hence, the device chosen was a metallic tape that would allow a more faithful sliding (shear) between the dentin and resin composite (Sinhoreti et al.; Braz et al., 2011). Also noteworthy, was the low numerical values found by the bond strength test, characteristic of this specific essay when a metallic tape was used. If these results are to be compared to similar studies, which have used other mechanical devices during the test (e.g. chisel), there should be caution in drawing up conclusive thoughts about the performance of the specific material in question (Sinhoreti et al.).

Even more, the prevalent fracture pattern in this study was cohesive in dentin, which had already been reported in a similar study in the literature (Yang et al.). It is believed that the combination of desensitizing toothpastes and remnants of the smear layer is unstable, and this is the most vulnerable (weak) part of the hybrid layer.

Thus, in face of the presented results, it is possible to infer that the different desensitizing tested toothpastes, even in simulated continuous use, were not able to interfere with the bonding ability to the dentin. However, these findings are limited to laboratory testing conditions; consequently, further clinical trials are necessary in order to support such information.

In conclusion, prolonged use of desensitizing toothpaste with $8 \%$ arginine/calcium carbonate, $8 \%$ strontium acetate and $5 \%$ calcium sodium phosphosilicate had no influence on bond strength of a self-etching adhesive system to dentin.

AGUIAR, J. D.; DE AMORIM, A. C. S.; MEDEIROS, I. S.; SOUZA JÚNIOR, M. H. S. \& LORETTO, S. C. Influencia del uso prolongado de pasta dentífrica desensibilizante en la fuerza de unión de la dentina de un sistema adhesivo autocondicionante. Int. J. Odontostomat., 10(1):135-142, 2016.

RESUMEN: La hipersensibilidad dentinaria es una condición clínica relativamente común, que afecta a una gran parte de la población mundial. El objetivo fue evaluar la influencia del tratamiento previo y prolongado con dentífricos desensibilizantes (DD) en fuerza de adhesión a la dentina, que promueve un sistema adhesivo de autograbado. Se utilizaron 70 incisivos bovinos no cariados, y se dividieron en cinco grupos $(n=14)$, de acuerdo con la pasta de dientes desensibilizante utilizada: G1: agua destilada (agua) (control), G2: Colgate Total 12 (CT12) (control), G3: Colgate Sensitive Pro-Alivio (CSPR), G4: Sensodyne Rápido Alivio (SRR) y G5: Sensodyne Repair \& Protect (SRP). Los dientes tenían sus superficies bucales aplanadas hasta la exposición de la dentina, y se obtuvieron fragmentos de $4 \times 4 \times 2$ $\mathrm{mm}$. Los fragmentos se incluyeron en cilindros de cloruro de polivinilo y se expusieron a $17 \%$ de EDTA durante un $1 \mathrm{~min}$. Después, las muestras se sometieron a 20000 ciclos de cepillado dental simulado. Después de $24 \mathrm{~h}$ en saliva artificial, las muestras se hibridaron (Clearfil SE Bond - Kuraray), y cilindros de resina compuesta fueron construidos sobre superficies de dentina. Las muestras se almacenaron en agua destilada, a $37^{\circ} \mathrm{C}$ durante 24 h y luego se determinó la 
resistencia al cizallamiento. El mayor valor de resistencia a la unión (MPa) se observó en el grupo CT12 $(4,39)$, y el menor en el grupo CSPR $(3,34)$. Los datos fueron analizados estadísticamente mediante ANOVA de un factor $1(\partial=$ $0,05)$, y los resultados no mostraron diferencias significativas $(p=0,5986)$ teniendo en cuenta el factor de los DD. El patrón de fractura predominante sobre la dentina fue el cohesivo. El uso previo y prolongado de diferente DD no afectó resistencia de unión a la dentina promovido por un sistema adhesivo de autograbado.

PALABRAS CLAVE: agentes desensibilizantes de la dentina, dentífricos, agentes de unión dentina, sensibilidad de la dentina.

\section{REFERENCES}

al-Salehi, S. K. \& Burke, F. J. Methods used in dentin bonding tests: an analysis of 50 investigations on bond strength. Quintessence Int., 28(11):717-23, 1997.

Aranha, A. C.; Siqueira Junior, Ade. S.; Cavalcante, L. M.; Pimenta, L. A. \& Marchi, G. M. Microtensile bond strengths of composite to dentin treated with desensitizer products. J. Adhes. Dent., 8(2):85-90, 2006.

Awang, R. A. R.; Masudi, S. M. \& Mohd Nor, W. Z. W. Effect of desensitizing agent on shear bond strength of an adhesive system. Arch. Orofac. Sci., 2:32-5, 2007.

Brännström, M.; Lindén, L. A. \& Aström, A. The hydrodynamics of the dental tubule and of pulp fluid. A discussion of its significance in relation to dentinal sensitivity. Caries Res., 1(4):310-7, 1967.

Braz, R.; Sinhoreti, M. A. C.; Spazzin, A. O.; Loretto, S. C.; de Castro Lyra, A. M. V. \& de Meira-Júnior, A. D. Shear bond strength test using different loading conditions a finite element analysis. Braz. J. Oral Sci., 9(4):43942, 2010.

Canares, G.; Salgado, T.; Pines, M. S. \& Wolff, M. S. Effect of an $8.0 \%$ arginine and calcium carbonate desensitizing toothpaste on shear dentin bond strength. J. Clin. Dent., 23(2):68-70, 2012.

Cavalcanti, A. N.; de Souza, E. S.; Lopes, G. S.; Freitas, A. P.; de Araújo, R. P. C. \& Mathias, P. Effect of a desensitizing dentifrice on the bond strength of different adhesive systems. Braz. J. Oral Sci., 12(2):148-52, 2013.

DeHoff, P. H.; Anusavice, K. J. \& Wang, Z. Three-dimensional finite element analysis of the shear bond test. Dent. Mater., 11(2):126-31, 1995.
Du Min, Q.; Bian, Z.; Jiang, H.; Greenspan, D. C.; Burwell, A. K.; Zhong, J. \& Tai, B. J. Clinical evaluation of a dentifrice containing calcium sodium phosphosilicate (novamin) for the treatment of dentin hypersensitivity. Am. J. Dent., 21(4):210-4, 2008.

Earl, J. S.; Leary, R. K.; Muller, K. H.; Langford, R. M. \& Greenspan, D. C. Physical and chemical characterization of dentin surface following treatment with NovaMin technology. J. Clin. Dent., 22(3):62-7, 2011.

Lavender, S. A.; Petrou, I.; Heu, R.; Stranick, M. A.; Cummins, D.; Kilpatrick-Liverman, L.; Sullivan, R. J. \& Santarpia, R. P. 3rd. Mode of action studies on a new desensitizing dentifrice containing $8.0 \%$ arginine, a high cleaning calcium carbonate system and $1450 \mathrm{ppm}$ fluoride. Am. J. Dent., 23(Spec. No. A):14A-9A, 2010.

Marchan, S.; White, D.; Pruszynski, J.; Manwah, T.; Bassaw, V. \& Smith W. The shear bond strengths of composite bonded to dentine following treatment with two dentine occluding desensitizing toothpastes. Open J Stomatol., 4(3):121-5, 2014.

Parolia, A.; Kundabala, M. \& Mohan, M. Management of dentinal hypersensitivity: a review. J. Calif. Dent. Assoc., 39(3):167-79, 2011.

Parkinson, C. R. \& Willson, R. J. An in vitro investigation of two currently marketed dentin tubule occlusion dentifrices. J. Clin. Dent., 22(1):6-10, 2011.

Pei, D.; Liu, S.; Huang, C.; Du, X.; Yang, H.; Wang, Y. \& Deng, D. Effect of pretreatment with calcium-containing desensitizer on the dentine bonding of mild self-etch adhesives. Eur. J. Oral Sci., 121(3 Pt. 1):204-10, 2013.

Porto, I. C.; Andrade, A. K. \& Montes, M. A. Diagnosis and treatment of dentinal hypersensitivity. J. Oral Sci., 51(3):323-32, 2009.

Sharif, M. O.; Iram, S. \& Brunton, P. A. Effectiveness of argininecontaining toothpastes in treating dentine hypersensitivity: a systematic review. J. Dent., 41(6):483-92, 2013.

Sinhoreti, M. A.; Consani, S.; De Goes, M. F.; Sobrinho, L. C. \& Knowles, J. C. Influence of loading types on the shear strength of the dentin-resin interface bonding. J. Mater. Sci. Mater. Med., 12(1):39-44, 2001.

Van Meerbeek, B.; Yoshihara, K.; Yoshida, Y.; Mine, A.; De Munck, J. \& Van Landuyt, K. L. State of the art of selfetch adhesives. Dent. Mater., 27(1):17-28, 2011.

Wang, Z.; Sa, Y.; Sauro, S.; Chen, H.; Xing, W.; Ma, X.; Jiang, T. \& Wang, Y. Effect of desensitising toothpastes on dentinal tubule occlusion: a dentine permeability measurement and SEM in vitro study. J. Dent., 38(5):40010, 2010. 
AGUIAR, J. D.; DE AMORIM, A. C. S.; MEDEIROS, I. S.; SOUZA JÚNIOR, M. H. S. \& LORETTO, S. C. Influence of prolonged use of desensitizing dentifrices on dentin bond strength of self-etching adhesive system. Int. J. Odontostomat., 10(1):135-142, 2016.

West, N. X. Dentine hypersensitivity: preventive and therapeutic approaches to treatment. Periodontol. 2000, 48:31-41, 2008.

West, N.; Newcombe, R. G.; Hughes, N.; Mason, S.; Maggio, B.; Sufi, F. \& Claydon, N. A 3-day randomised clinical study investigating the efficacy of two toothpastes, designed to occlude dentine tubules, for the treatment of dentine hypersensitivity. J. Dent., 41(2):187-94, 2013.

Yang, H.; Pei, D.; Chen, Z.; Lei, J.; Zhou, L. \& Huang, C. Effects of the application sequence of calcium-containing desensitising pastes during etch-and-rinse adhesive restoration. J. Dent., 42(9):1115-23, 2014.

Yoshida, Y.; Nagakane, K.; Fukuda, R.; Nakayama, Y.; Okazaki, M.; Shintani, H.; Inoue, S.; Tagawa, Y.; Suzuki, K.; De Munck, J. \& Van Meerbeek, B. Comparative study on adhesive performance of functional monomers. $J$. Dent. Res., 83(6):454-8, 2004.
Correspondence to:

Sandro Cordeiro Loretto

Avenida Conselheiro Furtado, 2312

Oásis, apto.401

CEP: 66040-100

Belém - Pará

BRASIL

Email: sandroloretto@hotmail.com

Received: 15-12-2015

Accepted: 28-03-2016 